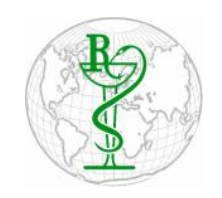

INDO GLOBAL JOURNAL OF

PHARMACEUTICAL SCIENCES

ISSN 2249- 1023

\title{
Medicinal Plants Used in Antenatal and Perinatal Care Among the Tiv People of Benue State, Nigeria
}

\author{
Erdoo P. Awai ${ }^{1}$, John O Igoli ${ }^{2 *}$ \\ ${ }^{1}$ Center for Sustainable Development, University of Ibadan, Oyo State, Nigeria \\ ${ }^{2}$ Department of Chemistry, University of Agriculture Makurdi, Benue State, Nigeria
}

Address for Correspondance: John O Igoli, igolij@gmail.com

\begin{abstract}
An ethnobotanical survey of plants used in prenatal or antenatal and perinatal care in the Tiv speaking areas of Benue State Nigeria is reported. A structured questionnaire was administered to informed respondents to document the traditional practices surrounding conception and contraception, abortion, delivery, prevention of preterm birth and infant mortality. The part of the plants used and purpose are presented. A scientific evaluation of these plants could lead to the development of new drugs to combat preterm birth and save the lives of millions of children worldwide especially in Africa and the developing countries. () 2014 iGlobal Research and Publishing Foundation. All rights reserved.
\end{abstract}

KEYWORDS: Traditional Medicine; Medicinal Plants; Preterm Birth; Antenatal; Perinatal; Tiv; Nigeria.

\section{INTRODUCTION}

Medicinal plants for centuries have been exploited for the treatment of diseases and healthcare. The discovery of new disease and health targets coupled with the emergence of drug resistance has rekindled interest in medicinal plants as sources of bioactive compounds for drug discovery [1-3]. Medicinal plants are better exploited when their ethnobotanical uses are considered. A present global concern is preterm birth as reports indicate that 15 million babies are born too soon and over one million die each year [4].This greatly affects farming populations and creates poverty as the women are perpetually engaged in childbearing and care. The reduction of infant mortality and improved maternal health in rural communities has taken a center stage in healthcare in the last decades. In Nigeria, some strategies adopted are the Midwife Service Scheme to increase access to skilled birth attendants thus reducing maternal, newborn and child mortality and the Kangaroo Mother Care aimed at providing care for preterm births [5].Achievements in this sector has been huge and according to the Nigerian Demographic Health Surveys (NDHS 2008, 2013) [6,7] there was a substantial decrease in the number of infant and child mortality between 2003 (513 per 1000 births) and 2013 (329 per 1000 births) [6].There was an increase in the proportion of women receiving antenatal care from 58\% in 2003 to $61 \%$ in 2013 but the median gestational age at first visit to a clinic has remained the same at five months over the same period. The percentage of women in the urban areas who received antenatal care was 86\% (67\% delivered in a health facility) while the percentage in the rural areas was $46.5 \%$ (22\% delivered in a health facility) however the number of births in the rural areas was double the number in the urban areas [6]. The Nigerian situation indicates that Infant mortality is directly related to the place of birth as exposure to risk factors which could lead to mortality varies from the urban to the rural areas [8].Over half of the infant mortalities in Nigeria occur at home. Data from $\mathrm{NDHS}^{8}$ also indicate that $35 \%$ births are in health facilities, $65 \%$ at home or others. About $80 \%$ of neonatal deaths are from preterm babies. Perinatal mortality rate in Nigeria is 39 deaths per 1,000 pregnancies. Nigerian newborns and under-five children also die as a result of malaria (20\%), pneumonia $(15 \%)$ and diarrhea $(18 \%)$. An underlying factor is malnutrition as one-third of all 


\section{Indo Global Journal of Pharmaceutical Sciences, 2015; 5(1): 90-93}

under-five children suffer from poor nutrition. Major causes of complications after five months of pregnancy are intra-partum related injury $(29 \%)$, preterm births (28\%) and severe infections (26\%). Other causes include environment, poverty, ignorance and poor health services. The main causes of maternal mortality are hemorrhage $(23 \%)$, infections $(17 \%)$, unsafe abortion (11\%), malaria (11\%), toxemia/eclampsia (11\%), HIV/AIDS (5\%) and others (6\%) [6-8].Traditional medicine and medicinal plants are genuinely involved in antenatal and perinatal care in Nigeria. Some of these plants have been used in traditional medicine or as food additives over the years by different cultures and have not been exposed to any scientific investigation. Although religiously inclined Nigerians consider traditional medicine to be evil as it unable to distinguish between treatments and witchcraft, at least one in two persons living in the rural communities use some form of traditional medicine for treatment and in the urban areas most people resort to traditional medicine when hope is lost from orthodox medicine. This study aims to expose through an ethnobotanical survey, the plants and practices involved in the prevention and management of neonatal, perinatal and preterm birth related complications and mortality amongst the Tiv people of central Nigeria. The Tiv people are well known for their long history of traditional medicine coupled with a rich flora of medicinal plants growing in their localities [911].They make up about $2.5 \%$ of the population and are distributed in Benue, Taraba, Nassarawa and Plateau states. Their major economic activities are farming, fishing, weaving and art work. Agriculture is the mainstay of their rural economy.

\section{METHODS}

Six local governments:Katsina-Ala, Kwande, Konshisha, Gboko, Guma, Gwer and Makurdi the state capital of Benue state were used for the study. Structured questionnaires were administered to the people coupled with in-depth interviews with identified Herbalists and Traditional birth attendants. Seventy questionnaires were administered; ten for each local government and at least one Herbalist or Traditional birth attendant were interviewed in each locality.

\section{RESULTS}

The plants, parts of plants and remedies or purpose for which they are used are presented in Table 1.The medicines are usually taken orally as concoctions or decoctions except in some cases where the medicines were applied topically. There were no specific dosages given for the traditional remedies but patients were encouraged to consume healthy volumes or continue treatment until relief from all symptoms is obtained.

\section{DISCUSSION}

$99 \%$ of the respondents in the local government areas accepted to have used herbs for one form of ailment or another.At least $90 \%$ of rural settlers confirmed the use herbal medicine either as contraceptives, for abortion and conception. $30 \%$ had ideasor information on the use of herbs for antenatal and preterm care. In the urban centers, $60 \%$ accepted to have used herbal medicine, $40 \%$ confirmed the use of herbs either as contraceptives or for abortion and conception while $10 \%$ had knowledge on the use of herbs for antenatal and preterm care. Ahigh percentage of the respondentsstill use traditional medicine for treatment. Some respondents complained of the lack of standardizationin traditional medicine as there is no dosage or accurate measure for the medicines, others for the association between traditional medicine and witchcraft. Constrains to the advancement or acceptability of traditional medicine include socio-economic and religious factors, lack of monographs or standardization ${ }^{12}$, lack of proper knowledge ontoxicity and the poor hygienic methods in their preparation. However, this study confirmed wide acceptability and dependence of the womenon these medicinal plants and practices as has been reported for other communities in Africa ${ }^{13}$.

\section{CONCLUSION}

Sustaining traditional medicine will go along way to save many species of plants from extinction, lead to the proper utilization of neglected species of plants, transfer of knowledge and skills which could lead to the discovery of new drugs. Therefore steps should be taken to ensure continuity of herbal medicine. Research in this area should employ a pro-traditional medicine campaign, encouraging personal hygiene and attemptregulation, control and dosage.Research results should be disseminated in simpler forms and made available to Herbalists and traditional birth attendants. Incentives should be provided to rural communities by research sponsors, governments or interested parties for sustainability of traditional medicine. Government should make legislative move towards complementing orthodox medicine with traditional medicine. Integrating or complementing orthodox medicine with traditional medicine could also be legislated. 


\section{Indo Global Journal of Pharmaceutical Sciences, 2015; 5(1): 90-93}

Table1: Medicinal plants, purpose and parts of plants used

\begin{tabular}{|c|c|c|c|c|}
\hline Scientific Name & Common Name & $\begin{array}{l}\text { Local or Tiv } \\
\text { Name }\end{array}$ & Use or purpose & Part(s) used \\
\hline Ocimumgratissimum & Tea bush & Kungulekuutamen & Preterm & Leaves \\
\hline Hibiscus sabdariffa & Guinea sorrel & Ashwe & Preterm & fruits \\
\hline Elaeisguineensis & Palm tree & Ikye & Preterm & Nuts \\
\hline Vitellariaparadoxa & Shea butter tree & Chamegh & Delivery & Fruits, Leaves \\
\hline Ceibapentandra & Cotton wood tree & Vambe & Delivery & Leaves \\
\hline Ceratothecasesasmoides & False sesame & Neen & Delivery & Leaves \\
\hline Grewiamollis & Savanna Grew tree & Hиеza & Delivery, Conception & Stem \\
\hline Lagenariasiceraria & Calabash gourd & Jondo & Conception & Leaves \\
\hline Maytenussenegalensis & Senegal maytenus & Alom & Conception & Stem \\
\hline Gardenia erubescens & $\begin{array}{l}\text { Pubescent edible } \\
\text { gardenia }\end{array}$ & Ishondou & Conception & Stem, Roots \\
\hline Annona senegalensis & Sour sop & Ahur & Conception & Stem, Roots \\
\hline Psidiumguajava & Guava & Gova & Conception & $\begin{array}{l}\text { Leaves, Fresh } \\
\text { branches/twigs }\end{array}$ \\
\hline Musa sapientum & Banana & Ayaba & Conception & stem \\
\hline Morindalucida & Brimestone tree & Akinde & Conception & Stem, Leaves \\
\hline Kigeliaafricana & Sausage tree & Tyembegh & $\begin{array}{l}\text { Conception, Internal } \\
\text { wounds }\end{array}$ & Back, Roots \\
\hline Senna Occidentalis & Negro coffee & Tsetsa & $\begin{array}{l}\text { Conception, open } \\
\text { wounds }\end{array}$ & Stem, Leaves \\
\hline Carica papaya & Pawpaw & Mbuer & Conception, Abortion & Leaves, Roots \\
\hline Stereospermumkunthianum & Kunth'sstereospemum & Umanatumba & Internal wounds & Stem \\
\hline Tephrosiapurpurea & Wild indigo & Agenga & Internal wounds & Stem \\
\hline Pavettacrassipes & Gland-leaf tree & Ato a ikpan & Internal wounds & Stem \\
\hline Mucunapruriens & Devil's bean & Imo & Stomach swellings & stem \\
\hline Nauclealatifolia & Savanna nauclea & Ikurakase & Jaundice & stem \\
\hline Commiphorakerstingii & $\begin{array}{l}\text { Smooth-back } \\
\text { commiphora }\end{array}$ & Avangeundunga & Jaundice & Stem \\
\hline Azadiractaindica & Neem & Dogoyaro & Abortion & Roots \\
\hline Lophiralanceolata & Savanna false shea & Ikuranomso & Abortion & Stem, Roots \\
\hline Burkeaafricana & Wild syringa & Gbagbongom & Abortion & Stem, Roots \\
\hline
\end{tabular}

\section{ACKNOWLEDGEMENTS}

The authors are grateful to the respondents and herbalists/traditional medicine practitioners who freely and willingly gave information in the course of this study.

\section{REFERENCES}

1. Gray, A.I., Igoli, J.O., Edrada-Ebel, R. Natural Products Isolation in Modern Drug Discovery Programs. In, Methods in Molecular Biology, 2012; 864: 515-534.

2. Ganesan, A.The impact of natural products upon modern drug discovery. Curr. Opin. Chem. Biol., 2008; 12: 306-317.

3. Newman, D.J., Cragg, G.M. Natural products as sources of new drugs over the last 25 years. J. Nat. Prod., 2007; 70: 461477.
4. Beck, S., Wojdyla, D., Say, L., Betran, A.P., Merialdi, M., Requejo, J.H., Rubens, C., Menon, R., Van Look, P.F.A. The worldwide incidence of preterm birth: a systematic review of maternal mortality and morbidity. Bull World Health Organization 2010; vol. 88 no. 1.

5. National Primary Health Care Development Agency, Nigeria. Briefing Manual on the MDG-DRG funded Midwives Service Scheme 2009; 7-70.

6. National Population commission Abuja. Nigeria Demographic and Health Survey (Preliminary Report) 2013: 13-32.

7. National Population Commission Abuja. Nigeria Demographic and Health Survey 2008: 117-160.

8. Archibong, E.I., Agan, T.U. Review of Policies and Programs for Reducing Maternal Mortality and Promoting Maternal Health in Cross River State, Nigeria. African J. Reproductive Health, 2010; 14(3): 42.

9. Agishi, E.C., Tiv, Idoma, Etulo, Igede, Akwaya, Hausa, English and Scientific Names of plants 2010. Agitab Publishers Makurdi: 2010: 14-25. 
Indo Global Journal of Pharmaceutical Sciences, 2015; 5(1): 90-93

10. Igoli, J.O., Tsenongo, S.N., Tor-Anyiin, T.A. A Survey of antivenomous, toxic and other plants used in some parts of Tivland, Nigeria. Int. J. Med. Aromatic Plants, 2011; 1(3): 240244.

11. Shomkegh, S.A., Mbakwe, R., Dagba, B.I. Ethnobotanical Survey of Edible Wild Plants in Tiv Communities of Benue State. Nigeria J. Nat. Sci. Res., 2013; 3(7): 17-23.
12. WHO traditional medicine strategy: 2014-2023; 25-40.

13. Malan, D.F., Neuba, D.F.R. Traditional Practices and Medicinal Plants Use during Pregnancy by Anyi-Ndenye Women (Eastern Côte d'Ivoire). African J. Reproductive Health, 2011; 15(1): 85-93.

Indo Global Journal of Pharmaceutical Sciences( ISSN 22491023 ; CODEN- IGJPAI; NLM ID: 101610675) indexed and abstracted in EMBASE(Elsevier), SCIRUS(Elsevier),CABI, CAB Abstracts, Chemical Abstract Services(CAS), American Chemical Society(ACS), Index Copernicus, EBSCO, DOAJ, Google Scholar and many more. For further details, visit 